\title{
Pengaruh Pembelajaran Inkuiri Menggunakan Kit IPA Terhadap Keterampilan Proses Sains Siswa Kelas VII SMPN 1 Tomini
}

\author{
Harun Nur Rosyid, Unggul Wahyono, dan I Wayan Darmadi \\ harunfisika10@gmail.com \\ Program Studi Pendidikan Fisika FKIP Universitas Tadulako \\ Jl. Soekarno Hatta Km. 9 Kampus Bumi Tadulako Tondo Palu - Sulawasi Tengah
}

\begin{abstract}
Abstrak - Penelitian ini bertujuan untuk mengetahui pengaruh pembelajaran inkuiri yang dilengkapi dengan penggunaan KIT IPA terhadap Keterampilan Proses Sains (KPS) siswa kelas VII SMPN 1 Tomini. Penelitian ini merupakan penelitian kuantitatif dengan model penelitian eksperimen. Pengambilan sampel dilakukan menggunakan teknik purpossive sampling dengan subyek yang digunakan adalah siswa kelas VII F SMPN 1 Tomini. Siswa yang menjadi subyek penelitian berjumlah 35 orang. Instrumen yang digunakan pada penelitian ini menggunakan tes essai yang terlebih dahulu di validasi dan diuji reliabilitasnya. Selanjutnya data dikumpulkan menggunakan teknik observasi dan di analisis uji normalitasnya, uji homogenitas dan uji -t untuk mengetahui hipotesis yang telah di buat sebelumnya. Hasil penelitian menunjukkan bahwa terjadi peningkatan keterampilan proses sains sebelum dan sesudah diberi perlakuan, sehingga terdapat pengaruh pembelajaran inkuiri menggunakan KIT IPA terhadap keterampilan proses sains siswa kelas VII SMPN 1 Tomini. Skor ratarata pretest sebesar 11 sedangkan skor rata-rata posttest sebesar 15,68 dengan presentase peningkatan keterampilan proses sains sebesar $54 \%$.
\end{abstract}

Kata Kunci: Pembelajaran Inkuiri; KIT IPA; keterampilan Proses Sains; purpossive sampling

\section{PENDAHULUAN}

Belajar menurut pandangan konstruktivistik adalah lebih dari sekedar mengingat. Seseorang yang memahami dan mampu menerapkan pengetahuan yang telah dipelajari, mereka harus mampu memecahkan masalah sendiri, menemukan (discovery) sesuatu untuk dirinya sendiri, dan berkutat dengan berbagai gagasan. Lebih lanjut menurut pandangan ini siswa harus menemukan dan mentransformasikan informasi kompleks ke dalam dirinya sendiri. Menurut Anni dkk (2004) Teori ini memandang siswa sebagai individu yang selalu memeriksa informasi baru yang berlawanan dengan prinsip-prinsip yang telah ada dan merevisi prinsip-prinsip tersebut apabila sudah dianggap tidak dapat digunakan lagi.

Pembelajaran dengan penemuan (inquiry) merupakan satu komponen penting dalam melakukan pendekatan konstruktivistik. Pembelajaran dengan penemuan mendorong siswa untuk memiliki pengalaman dan melakukan percobaan yang memungkinkan menemukan prinsip prinsip mereka sendiri.

Pada dasarnya sains bertujuan menjelaskan fenomena alam. Oleh karena itu cara belajar sains harus melibatkan siswa pada pengalaman. Melalui pembelajaran sains dapat dibangun berbagai keterampilan tingkat tinggi. Adapun kekuatan pembelajaran sains yang dapat membangun kemampuan berpikir siswa terletak pada kemampuan berhipotesis.
Menurut liliasari (2005) kemampuan berpikir ini kurang dapat berkembang pada pembelajaran sains, apabila tidak diikuti dengan eksperimen atau praktikum. Seperti halnya pembelajaran sains yang ditemukan di sekolah-sekolah di Indonesia pada umumnya.

Sains pada dasarnya tidak terlepas dari pengamatan dan pengalaman. Agar pengamatan memberikan hasil yang maksimal perlu adanya sebuah alat penunjang misalnya sebuah paket alat praktikum atau biasa disebut dengan KIT (Komponen Instrumen Terpadu). KIT merupakan sebuah peralatan yang diproduksi dan dikemas dalam kotak unit pengajaran yang menyerupai rangkaian peralatan uji coba/eksperimen dan dilengkapi dengan buku pedoman penggunaannya. Dengan menggunakan KIT, peserta didik diajak untuk merasakan proses gejala alam yang sudah pernah dilakukan oleh para ilmuwan sehingga mereka tidak hanya mendapatkan pengetahuan tetapi juga mendapatkan pengalaman dalam proses pembelajaran. Olehnya itu pemanfaatan media praktikum dirasakan sangat perlu dimanfaatkan semaksimal mungkin agar pembelajaran sains memperoleh hasil yang maksimal. Hal ini senada dengan penelitian yang dilakukan oleh Widayanto (2009) pemanfaatan KIT IPA mampu mengembangkan kemampuan keterampilan proses sains dan pemahaman siswa kelas X-C SMAN 3 Sragen. Menurutnya faktor penting dalam peningkatan keterampilan proses sains 
dan pemahaman siswa adalah keterlibatan siswa dalam kegiatan praktikum. Semakin tinggi keterlibatan siswa dalam kegiatan praktikum semakin tinggi pencapaian pemahaman dan keterampilan proses sains siswa.

Berdasarkan hasil observasi di SMPN 1 Tomini diketahui bahwa umumnya guru dalam proses pembelajaran sains masih sangat kurang memanfaatkan alat peraga yang ada di laboratorium, tetapi cenderung lebih banyak memberikan informasi. Umumnya dalam pembelajaran cenderung lebih sering menggunakan buku sebagai sumber informasi. Disamping itu minat siswa terhadap buku sebagai sumber referensi mulai menurun, melainkan lebih banyak menggunakan internet. Akibatnya siswa lebih banyak berkutat di dunia informasi dibandingkan mengalami konstruksi pengetahuan fisikanya secara nyata. Hal ini berimplikasi pada keterampilan proses sains siswa yang relatif rendah.

Menurut Hamalik (2001) belajar adalah modifikasi atau memperteguh kelakuan melalui pengalaman. Menurut pengertian ini belajar merupakan suatu proses, suatu kegiatan dan bukan suatu hasil atau tujuan. Belajar bukan hanya mengingat, akan tetapi lebih luas dari itu yakni mengalami. Hasil belajar bukan suatu penguasaan hasil latihan melainkan perubahan kelakuan itu sendiri.

Fisika merupakan salah satu pelajaran yang menggabungkan antara gejala alam dan ilmu matematis dalam sebuah teori. Umumnya teori yang disajikan terasa abstrak sehingga sering begitu sulit untuk dipahami. Kesulitan dalam memahami konsep atau teori itu umumnya adalah dalam hal melakukan interpretasi. Sehingga siswa perlu memiliki keterampilan proses yang tepat agar mudah dalam memahami teori-teori fisika tersebut.

Pendidikan fisika harus dapat menjadi pendorong yang kuat tumbuhnya sikap rasa ingin tahu dan keterbukaan terhadap ide-ide baru maupun kebiasaan berpikir kuantitatif. Dalam diri siswa sebaiknya ditumbuhkan kesadaran agar dapat melihat fisika bukan semata-mata sebagai kegiatan akademik, tetapi lebih sebagai cara untuk memahami dunia tempat mereka hidup (Mundilarto, 2002)

\section{METODOLOGI PENELITIAN}

Penelitian ini merupakan penelitian kuantitatif, dengan menggunakan metode penelitian eksperimen.

Rumusan masalah dalam penelitian ini yaitu apakah terdapat pengaruh pembelajaran menggunakan KIT IPA terhadap keterampilan proses sains siswa kelas VII SMPN 1 Tomini. mengetahui pengaruh pembelajaran pada mata pelajaran fisika untuk siswa SMP yang memanfaatkan media/KIT sebagai objeknya. Dengan pemanfaatan KIT IPA bertujuan agar pembelajaran lebih sistematis, dan mempermudah pemahaman siswa sehingga dapat meningkatkan keterampilan proses sains siswa khususnya pada mata pelajaran fisika.

Penelitian ini dilakukan pada siswa yang telah mendapatkan materi suhu dan kalor pada siswa kelas VII SMPN 1 Tomini. Sampel pada penilitian ini yaitu kelas VII $F$ dengan jumlah 35 orang. Pemilihan sampel berdasarkan teknik purposive sampling [10].

Instrumen pada penelitian ini menggunakan tes essai yang sebelumnya diuji validasi dan diuji reliabilitasnya. kemudian data yang diperoleh dianalisis distribusi normalnya, homogenitasnya dan uji-t untuk menentukan hipotesis yang telah dibuat sebelumnya.

Data yang dikumpulkan berupa skor hasil tes essai dengan indikator keterampilan proses sains yaitu membuat hipotesis, mengidentifikasi varabel, mengamati, mengukur dan membuat kesimpulan.

\section{HASIL DAN PEMBAHASAN}

Penelitian ini dilakukan pada siswa kelas VII F SMPN 1 Tomini. Perhitungan data dilakukan menggunakan bantuan software statisti yaitu Statistical Product and Service Solution (SPSS).

Pengujian data dilaksanakan dengan 2 tahap, yaitu analisa data instrumen dan analisa data statistik.

Analisa data instrumen menggunakan 2 metode, yaitu validasi konstrak dan uji reliabilitas. Validasi konstrak yaitu menggunakan jenis validasi konstrak, dimana menurut Sugiyono (2013) setelah instruman dikonstruksi tentang aspek-aspek yang akan diukur dengan berlandaskan teori tertentu, maka selanjutnya dikonsultasikan dengan ahli. Selanjutnya instrumen dikonversi dalam sebuah data untuk dihitung reliabilitasnya. Adapun hasil reliabilitas pada penelitian ini sebagai berikut:

\begin{tabular}{cc}
$\frac{\text { TABEL 1. UJI RELIABILITAS }}{\text { Reliability Statistics }}$ \\
\hline Cronbach's Alpha & N of Items \\
\hline 0,496 & 10 \\
\hline
\end{tabular}

Syarat data dikatakan reliabel yaitu apabila rhitung $>$ rtabel. Dari data diatas dapat dilihat nilai reliabilitas untuk 10 item soal sebesar 0,496. Selanjutnya kita merujuk pada tabel untuk $\mathrm{N}=35$ dengan taraf signifikansi 0,05 diperoleh $r_{\text {tabel }}$ sebesar 0,334. Karena nilai rhitung lebih 
p-ISSN 2338-3240, e-ISSN 2580-5924

besar daripada nilai rtabel atau 0,496>0,334 maka instrumen yang digunakan pada penelitian ini dinyatakan reliabel.

Merujuk pada pendapat Arikunto untuk koefisien reliabilitas sebesar 0,496 termasuk dalam kategori sedang dengan rentang nilai $0,40<$ rxy $\leq 0,60$. Hal ini menunjukan bahwa instrumen pada penelitian ini sudah memenuhi syarat reliabilitas.

Pengujian berikutnya yaitu untuk melihat apakah data berasal dari populasi yang terdistribusi normal. Pada penelitian ini data dihitung menggunakan SPSS melalui uji kolmogorov-smirnov. Adapun hasil uji normalitas pada penelitian ini adalah sebagai berikut :

TABEL 2. UJI NORMALITAS

\begin{tabular}{llccc}
\multicolumn{5}{c}{ Tests of Normality } \\
\cline { 3 - 5 } Uji & & \multicolumn{3}{c}{ Kolmogorov-Smirnov } \\
\cline { 2 - 5 } & & statistik & df & sig. \\
\hline \multirow{2}{*}{ Tes_KPS } & Pretest & 0,130 & 35 & 0,143 \\
& Posttest & 0,112 & 35 & $0,200^{*}$ \\
\hline
\end{tabular}

$*$. This is a lower bound of the true significance.

a. Lilliefors Significance Correction

Data yang sudah diuji dikatakan terdistribusi normal apabila memiliki taraf signifikansi $>a$, dengan nilai $a=0,05$. Sebaliknya apabila taraf signifikansi < a maka data tidak terdistribusi normal.

Berdasarkan data diatas terlihat bahwa taraf signifikansi uji pretest pada tabel KolmogorvSmirnov sebesar 0,143 . Karena nilai $0,143>0,05$ maka data pretest dikatakan terdistribusi normal. Begitu pula pada data posttest taraf signifikansi yang diperoleh sebesar 0,200>0,05 maka untuk data posttest HO diterima atau data berasal dari populasi yang terdistribusi normal.

Pengujian data berikutnya yaitu uji homogenitas. Pengujian ini untuk melihat apakah data berasal dari populasi yang homogen. Data homogen merupakan syarat agar data dari hasil penelitian layak untuk dilakukan uji hipotesis melalui uji-t dua pihak maupun satu pihak. pada tahap ini data dihitung menggunakan SPSS melalui uji Levene. Adapun hasil pengujian data homogen adalah sebagai berikut :
TABEL 3. UJI HOMOGENITAS

Test of Homogeneity of $\mathrm{V}$ ariance

\begin{tabular}{|l|r|r|r|c|}
\hline & $\begin{array}{c}\text { Levene } \\
\text { Statistic }\end{array}$ & df1 & df2 & Sig. \\
\hline Based on Mean & 0,537 & 1 & 68 & 0,466 \\
Based on Median & 0,412 & 1 & 68 & 0,523 \\
Tes_K Based on Median & 0,412 & 1 & 64,59 & 0,523 \\
PS and with adjusted & & & 4 & \\
df & & & & \\
Based on trimmed & 0,518 & 1 & 68 & 0,474 \\
mean & & & & \\
\hline
\end{tabular}

Uji prasyarat untuk menentukan apakah data homogen atau tidak yaitu apabila taraf signifikansi>a, dengan nilai a sebesar 0,050 maka data tergolong dalam data yang homogen. Berdasarkan data diatas terlihat bahwa pada Based on mean atau berdasarkan nilai rata-rata taraf signifikansi data sebesar 0,466 . Nilai ini jika kita sesuaikan dengan uji prasyarat diatas maka $0,466>0,050$ sehingga data tergolong dalam data yang homogen.

Uji data selanjutnya yaitu uji

peningkatan keterampilan proses sains menggunakan rumus $\mathrm{N}$-Gain. Rumus tersebut digunakan untuk melihat sejauhmana perbedaan kondisi sebelum dan sesudah diberi perlakuan. Adapun hasil uji peningkatan keterampilan proses sains adalah sebagai berikut:

\begin{tabular}{ll} 
TABEL 4. UJI PENINGKATAN KETERAMPILAN PROSES SAINS \\
\hline \multicolumn{1}{c}{ Uraian } & Jumlah \\
\hline Sampel & 35 orang \\
Siswa dengan nilai rendah & 3 orang \\
Siswa dengan nilai sedang & 27 orang \\
Siswa dengan nilai tinggi & 5 orang \\
Nilai Rata-Rata N-Gain & $54 \%$ \\
\hline
\end{tabular}

Data hasil perhitungan N-Gain berasal dari skor rata rata keterampilan proses sebelum diberi perlakuan sebesar 11 sedangkan skor rata-rata setelah diberi perlakuan sebesar 15,68 ( lampiran 17 ). Selanjutnya diperoleh NGain dari rata-rata pretest dan posttestdengan presentase sebesar 54\%. Adapun tingkatan nilai N-Gain termasuk dalam kategori rendah apabila $\mathrm{g}<30$, selanjutnya termasuk dalam kategori sedang apabila $30<\mathrm{g}<70$, dan termasuk dalam kategori tinggi apabila $\mathrm{g}>70$. Sesuai dengan syarat $\mathrm{N}$-Gain maka dari data yang diperoleh menunjukan bahwa rataratapeningkatan keterampilan proses sains siswa sesuai kriteria N-Gain termasuk dalam kategori sedang.

Pengolahan data selanjutnya yaitu uji hipotesis.Uji hipotesis ini menggunakan uji statistik parametrik uji " $t$ ". Uji yang digunakan 
untuk hipotesis ini adalah uji dua pihak. Adapun hipotesis yang diajukan yaitu :

$$
\begin{aligned}
& \mathrm{H}_{0}: \mu_{\text {post }}=\mu_{\text {pre }} \quad \text { : Tidak terdapat } \\
& \text { perbedaan rata-rata } \\
& \text { skor keterampilan } \\
& \text { proses sains sebelum } \\
& \text { dan sesudah diberi } \\
& \text { pembelajaran } \\
& \text { menggunakan KIT IPA. } \\
& \mathrm{H}_{1}: \mu_{\text {post }} \neq \mu_{\text {pre }} \quad \text { : Terdapat perbedaan } \\
& \text { rata-rata skor } \\
& \text { keterampilan proses } \\
& \text { sains sebelum dan } \\
& \text { sesudah diberi } \\
& \text { pembelajaran } \\
& \text { menggunakan KIT IPA. }
\end{aligned}
$$

Adapun syarat $\mathrm{H}_{0}$ diterima apabila taraf signifikansi $>0,05$, sebaliknya apabila taraf signifikansi $<0,05$ maka $\mathrm{H}_{0}$ ditolak. Adapun hasil uji hipotesi yang diperoleh adalah sebagai berikut :

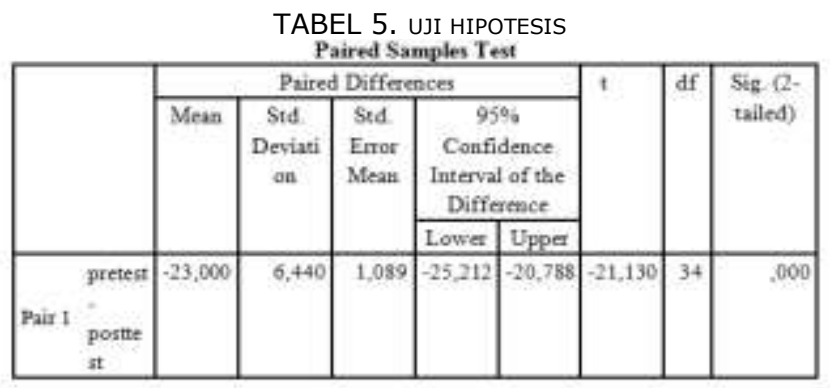

Berdasarkan Tabel 4.5 terlihat bahwa taraf Signifikansi sebesar 0,00 sehingga perbandingan signifikansi diperoleh $0,00<$ 0,05 . Selain itu untuk perbandingan nilai $t$ diperoleh |thitung| $>$ ttabel dengan menggunakan uji dua pihak yaitu $|-21,13|>$ 2,03 . Dari hasil perhitungan tersebut maka daerah hipotesisberada diluar daerah penerimaan Ho. Dengan demikian dapat disimpulkan bahwa terdapat perbedaan ratarata Keterampilan Proses Sains sebelum dan sesudah diberi pembelajaran menggunakan KIT IPA.

Berdasarkan Uji peningkatan keterampilan proses sains untuk nilai pretest dan posttest diperoleh dalam penelitian ini sebesar 54\% sehingga nilai ini termasuk dalam kategori sedang. Lebih lanjut dari uji-t diperoleh kesimpulan bahwa terdapat perbedaan ratarata Keterampilan Proses Sains siswa baik yang sebelum diberi perlakuan maupun yang sesudah diberi perlakuan dengan nilai mutlak thitung sebesar 21,13.

Pembelajaran dalam penelitian ini menggunakan model pembelajaran inkuiri Model pembelajaran inkuiri digunakan karena dianggap pembelajaran yang paling layak untuk menerapkan pendekatan keterampilan proses sains. Langkah-langkah pembelajaran inkuiri yang digunakan meliputi pengarahan untuk merumuskan hipotesa, merancang percobaan, melakukan observasi, melakukan pengukuran, dan membuat sebuah kesimpulan.

Pada penelitian ini juga digunakan KIT IPA sebagai bahan ajar untuk mempermudah pembelajaran. Kelebihan yang diperoleh selama menggunakan alat ini misalnya praktis dan mudah digunakan, dapat menarik perhatian siswa, dapat menganalogikan konsep yang ingin disampaikan kepada siswa secara langsung. Adapun kekurangannya yaitu banyak alat-alat yang tersedia telah rusak dan diantaranya ada sebagian alat-alat yang tidak digunakan, sehingga guru harus mencari cara kreatif untuk menutupi kekurangan tersebut. Hal ini dikarenakan pengelolaan alat laboratorium di sekolah yang belum maksimal. Selain itu petunjuk pemakaian yang belum terlalu jelas sehingga guru mengalami kesulitan dalam memanfaatkan alat tersebut. Hal ini senada dengan yang diungkapkan oleh Arsyad (2004) bahwa alat peraga memiliki kekurangan memiliki keterbatasan sumber dan keterampilan guru untuk menjelaskan dan memanfaatkannya.

Keberadaan KIT IPA sebagai alat peraga memberikan pengalaman yang nyata dan dapat menumbuhkan kegiatan berusaha sendiri pada setiap siswa. Selain itu keberadaan alat peraga memberikan pengalaman yang tidak mudah diperoleh dengan cara lain. Dengan demikian penggunaan alat peraga dalam proses belajar mengajar dapat membantu siswa mempermudah untuk memahami suatu konsep atau prinsip yang diajarkan. Lebih lanjut Nana Sudjana (2002) mengemukakan bahwa fungsi pokok dari alat peraga dalam proses belajar mengajar yaitu dalam proses belajar mengajar alat peraga bukan merupakan fungsi tambahan tetapi memiliki fungsi tersendiri sebagai alat bantu untuk mewujudkan situasi belajar mengajar yang efektif.

Berdasarkan hasil penelitian terhadap siswa, dapat dinyatakan bahwa terjadinya perbedaan antara pretest dan posttest. Peningkatan tersebut terjadi karena siswa mulai terbiasa dalam mengerjakan soal-soal yang berkaitan dengan keterampilan Proses Sains siswa melalui latihan praktikum maupun pembuatan laporan hasil praktikum. Pada Akhirnya siswa lebih terlatih dalam menyelesaikan masalah fisika yang berangkat dari kehidupan seharihari. Siswa menjadi menjadi lebih peka terhadap fenomena yang mereka lihat dan mampu menyelesaikan masalah serta dapat 
melatih keterampilan siswa dalam penemuan konsep sains secara mandiri.

\section{KESIMPULAN}

Berdasarkan hasil penelitian dan analisis data yang diperoleh, maka dapat disimpulkan bahwa terdapat pengaruh pembelajaran inkuiri menggunakan KIT IPA terhadap keterampilan proses sains siswa SMP Negeri 1 Tomini sebelum diberi perlakuan dan setelah diberi perlakuan. Hal ini dapat diketahui dari uji NGain maupun uji-t. Pada penelitian ini nilai NGain yang diperoleh sebesar $54 \%$, Sedangkan dari uji-t dua pihak di peroleh taraf signifikansi hasil perhitungan SPSS sebesar 0,000 dengan taraf nyata sebesar 0,050 . Karena $0,000<0,050$ maka hipotesis nol ( $\mathrm{Ho}$ ) ditolak dan hipotesis satu $\left(\mathrm{H}_{1}\right)$ diterima.

\section{DAFTAR PUSTAKA}

[1] Adeyemo, S. A. (2010). Background and classroom correlates of students' achievement in Physics. Dalam International Journal of Educational Research and Technology [Online], vol 1, 25 - 34. Tersedia: http://www.journals.elsevier.com/international-journal -of-educational-research/. [16 Agustus 2014]

[2] Rodrigues,A.and Oliveira,M. (2008). The role of critical thinking in physics learning. [Online]. Tersedia: http://lsg.ucy.ac.cy/girep2008/papers/THE\%20ROLE
\%200F\%20CRITICAL\%20THINKING.pdf. [22 Februari 2014].

[3] Kemendiknas. (2013). Lampiran Peraturan Menteri Pendidikan Dan Kebudayaan Nomor 69 Tahun 2013 tentang Kerangka Dasar dan Struktur Kurikulum Sekolah Menengah Atas/Madrasah Aliyah. Jakarta: Departemen Pendidikan dan Kebudayaan.

[4] Brookhart, S. M. (2010). How to Asses Higher-Order Thinking Skills in your Classroom. Alexandria: ASCD.

[5] Santrock, J. W. (2003). Adolescence Perkembangan Remaja. Jakarta: Erlangga.

[6] Lewy, Z. dan Aisyah, N.. (2009). "Pengembangan Soal untuk Mengukur Kemampuan Berpikir Tingkat Tinggi Pokok Bahasan Barisan dan Deret Bilangan di Kelas IX Akselerasi SMP Xaverius Maria Palembang". Jurnal Pendidikan Matematika. 3, (2), 14-28.

[7] Thompson, T. (2009). An Analysis of Higher-Order Thinking on Algebra I End-of Course Tests. [Online]. Tersedia:

http://www.cimt.plymouth.ac.uk/journal/thompson.pd f. [22 Februari 2014].

[8] Rosnawati, R. (2009). Enam Tahapan Aktivitas dalam Pembelajaran MatematikaUntuk Mendayagunakan Berpikir Tingkat Tinggi Siswa, Makalah pada Seminar Nasional, in press.

[9] Kurniawati, Wahyu. (2013). "Pengembangan Perangkat Perkuliahan IPA dengan Pendekatan Problem Based Learning untuk meningkatkan Keterampilan Higher Order Thinking Mahasiswa Program Studi Pendidikan Guru Sekolah Dasar". Elementary Schools. 1, (1), 55-56.

[10] Sugiyono. (2013). Metode Penelitian Pendidikan Pendekatan Kuantitatif, Kualtitatif dan R\&D. Bandung: Alfabeta. 